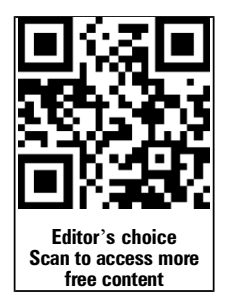

Department of Kinesiology and Physical Education, McGill University, Montreal, Quebec, Canada

\section{Correspondence to} Jeff Caron, Department of Kinesiology and Physical Education, McGill University, 475 Pine Avenue West, Montreal, QC, Canada H2W1S4;

jeffrey.caron@mail.mcgill.ca

Received 3 November 2014 Revised 3 March 2015 Accepted 8 March 2015 Published Online First 30 March 2015

\section{CrossMark}

To cite: Caron JG Bloom GA, Falcão WR, et al. Inj Prev 2015;21:301-308.

\title{
An examination of concussion education programmes: a scoping review methodology
}

\author{
Jeffrey G Caron, Gordon A Bloom, William R Falcão, Shane N Sweet
}

ABSTRACT

Objectives The primary purpose was to review the literature on concussion education programmes. The secondary purpose was to inform knowledge translation strategies for concussion researchers and practitioners.

Design Research on concussion education programmes is relatively new. As a result, the current study implemented a scoping review methodology, which is a type of literary search used to provide a preliminary assessment of the size and scope of a body of literature, as well as identify strengths, weaknesses and gaps in the research.

Methods A five-stage process for conducting a scoping review was followed for this study: (a) identifying the research questions, (b) identifying relevant studies, (c) identifying the study selection criteria, (d) charting the data and (e) reporting the results.

Results Concussion education programmes have been developed and implemented with populations ranging in age from 9 to 49 years and have used interactive oral presentations, educational videos and computer-based learning programmes. Although the content of these programmes varied, the topics generally addressed salient aspects of concussion injury and recovery. Quantitative instruments have been the preferred methods for assessment.

Conclusions Education programmes aimed at improving participants' long-term concussion knowledge, behaviours and attitudes of concussions are needed. Researchers must consider using a knowledge translation framework to enhance concussion education programmes. The application of such a framework can lead to novel and interesting ways of disseminating information about concussive injury and recovery.

\section{INTRODUCTION}

Sports-related concussions affect athletes of all age and skill levels, as well as parents, family members, coaches and clinicians. ${ }^{12}$ Concussions have a symptomatology that ranges from headaches, dizziness and nausea to irritability, anxiety and depression. ${ }^{3}$ The severity of these symptoms is influenced by a number of factors such as age, gender and history with the injury. ${ }^{3}$ The growing awareness surrounding the short-term and long-term consequences of concussions has concerned stakeholders in sport, and more recently, governments. In May 2014, American President Barack Obama held a summit on youth sport concussions at the White House where he convened leading experts to discuss the future of concussive injury and recovery. The president's decision to make concussions a public health issue is indicative of the growing awareness about the injury and its impact on public health, both inside and outside the sporting community.
Additionally, concussion awareness has influenced legislative branches of American government to mandate concussion education in all 50 states. $^{4} 5$ Despite an ever-increasing body of research and public awareness about concussive injury and recovery, relatively little is known about the most effective ways to disseminate this information to knowledge users (ie, athletes, coaches, parents and clinicians). ${ }^{3}{ }^{6}$ Knowledge translation (KT) strategies could be the 'missing link' to improving the dissemination of concussion information to these knowledge users (ref. 7, p. 69).

KT is defined as "the dynamic and iterative process that includes synthesis, dissemination, exchange and ethically-sound application of knowledge...”. ${ }^{8}$ KT aims to bridge the knowledge gap between the scientific community and knowledge users. ${ }^{9}$ The knowledge to action cycle is one framework to examine the knowledge gap. ${ }^{10}$ The knowledge to action cycle comprised two sections, whereby (a) the knowledge funnel consists of refining information from basic research to the creation of a knowledge tool/product, and (b) the action cycle represents the process of implementing and evaluating the knowledge tool/product. This framework has been suggested as a potential approach to examine the KT of concussion research. ${ }^{6}$ One of the most recommended and widely implemented concussion KT strategies to date is concussion education.

It is imperative that concussion education strategies are adapted to the specific audience/local context (eg, student-athletes vs physicians), that barriers and facilitators of knowledge use are assessed and the proper intervention strategy is chosen, implemented and evaluated. ${ }^{8}$ Unfortunately, these elements have not been consistently used when developing concussion education strategies. For example, concussion education has been dominated by passive educational strategies, such as printed materials and handouts (eg, CDC's Heads Up concussion initiative $)^{11-14}$ and concussion-related websites. $^{3}{ }^{615}$ Printed materials and handouts have allowed for concussion information to be disseminated to people inside and outside the sporting community; ${ }^{11}$ however, some have questioned whether passive education could lead to behaviour change when used as a standalone strategy. ${ }^{16}$ Additionally, concussion-related websites often contain medical jargon, ${ }^{15}$ making the content difficult to understand for non-medical knowledge users. ${ }^{9}$ Taken together, the current concussion education strategies may not have been properly adapted to the local context (eg, websites) and that the type of strategy (eg, handouts) may not be most effective. 
As a result, other types of strategies need to be implemented and evaluated, such as concussion education programmes, which some feel are a more optimal type of concussion education strategy given their interactive nature. ${ }^{7}$ Although there is no agreedupon definition, concussion education programmes will be operationally defined as any formal programme that teaches a population about aspects of concussions that is beyond passive materials (eg, handouts and websites). Because little is known about the breadth of research on concussion education programmes, a detailed review focusing on the state of concussion education programmes is timely. This review would also help advance the science and practice of KT strategies with concussions.

According to Grant and Booth, ${ }^{17}$ there are at least 14 types of literature reviews that have been used to summarise bodies of research. Selecting a type of review depends on a number of factors such as the breadth of literature in a given area and intended outcomes of the review. ${ }^{17}{ }^{18}$ Scoping reviews are literary searches that are used to provide a preliminary assessment of the size and scope of a body of literature as well as identify strengths, weaknesses and gaps in the research. ${ }^{18}{ }^{19}$ Scoping reviews have been used to summarise bodies of literature on concussion rehabilitation strategies ${ }^{20}$ and on other health-related issues like Alzheimer's disease, ${ }^{21}$ HIV rehabilitation ${ }^{22}$ and in settings such as trauma centres ${ }^{23}$ and intensive care facilities. ${ }^{24}$ Because research on concussion education programmes is relatively new, a scoping review is ideal to determine the state of these education programmes. Therefore, the first purpose of this study was to review the literature by identifying strengths, weaknesses and gaps in concussion education programmes using a scoping review methodology. The secondary purpose was to inform KT strategies with concussions.

\section{METHODS}

Levac et al's ${ }^{19}$ five-stage process for conducting a scoping review was followed for this study. Specifically, the five stages included (a) identifying the research questions, (b) identifying relevant studies, (c) identifying the study selection criteria, (d) charting the data and (e) reporting the results. The first four stages will be described in this section, whereas the fifth stage will be detailed in the 'Results' section.

\section{Identifying the research questions}

The specific research questions guiding this work were: what populations have been included in concussion education programmes? What types of education programmes have been developed to disseminate concussion information? What is the content of concussion education programmes? What instruments have been used to assess concussion education programmes? What are the outcomes of these programmes?

\section{Identifying relevant studies}

Databases commonly used with other literary searches on concussions were used to locate articles for this study, including ERIC (ProQuest), Medline, PsycINFO, SPORTDiscus and Web of Science. Keywords related to concussions (ie, concuss* OR "brain concuss"” OR "brain injur*" OR "sport concuss"”) and education programs (ie, educat" OR "educat* intervention"* OR "concuss" educat"” OR "educat" program"”) were entered into each database. The search was refined by searching the databases for concussion 'AND' education program keywords.

\section{Identifying the study selection criteria}

In order to meet the selection criteria for this scoping review, articles must have (a) been written in English; (b) been an original article (ie, not a review study or book chapter); (c) had a full-text copy available in one of the selected databases by 21 February 2014; (d) described an educational programme that teaches a population about concussions, not including websites, handouts or other types of passive educational materials; and (e) used the term 'concussion' as defined by the Concussion in Sport group. ${ }^{3}$ Given that concussions are classified as a type of mild traumatic brain injury (mTBI), it is challenging to distinguish between mTBI and concussion. Indeed, experts have noted the terms are "often used interchangeably in the sporting context and particularly in the United States literature" (ref. 3, p. 250). However, the terms refer to different injury constructs. ${ }^{3}$ As a result, the current study selected articles that educated a population about 'concussions'.

\section{Charting the data}

The research process is presented in figure 1 and outlines the number of articles included and discarded at each stage as well as the rationale for their exclusion.

\section{RESULTS}

A total of 5938 records were retrieved from the five databases selected for this study. The initial search revealed seven articles that matched the selection criteria. Two additional articles were located via manual search. A total of nine articles were included in this scoping review. Disputes regarding article inclusion/exclusion were resolved by consensus among the authors. Table 1 provides a detailed description of each of the nine studies in relation to the purpose and research questions identified for this scoping review. The remainder of this section will provide a synthesis of the main findings from each of the studies.

Overall, the concussion education programmes included in this review were designed and implemented for populations that ranged from 9 to 49 years of age. Specifically, six concussion education programmes were developed for athlete populations, ${ }^{25-30}$ one for elementary and high school students, ${ }^{31}$ one for university students ${ }^{32}$ and one for coaches. ${ }^{33}$

The nine concussion education programmes included in this review can be divided into interactive oral presentations, educational videos and computer-based learning programmes. Despite variations in the type of programme, each was administered at one time point only. Four studies used interactive oral presentations to educate their populations about concussions, ${ }^{29-32}$ which consisted of a lecture-style format, with brief video segments and discussions incorporated within the seminar. Three of these interactive oral presentations lasted between 20 and 30 $\min ^{29} 3032$ while one was $40-60$ min in length. ${ }^{31}$ Two other concussion education programmes were based on an educational video created by ThinkFirst, a Canadian non-profit organisation dedicated to preventing brain and spinal cord injuries, called Smart Hockey: More Safety, More Fun. ${ }^{25} 26$ The concussion education video lasted approximately $25 \mathrm{~min}$. Another three studies mainly used computer-based learning programmes to disseminate their concussion education programme. ${ }^{27} 28 \quad 33$ It was unclear how long participants were exposed to computer-based learning programmes.

The content of concussion education programmes varied greatly among the nine studies. The most popular features were concussion symptoms, ${ }^{28-32}$ followed by management strategies, ${ }^{29} 3233$ long-term sequelae ${ }^{29-31}$ and the return to play protocol. $^{26} 3032$ Interestingly, only one of the nine studies ${ }^{33}$ noted the content of their concussion education programme was based on peer-reviewed expert guidelines. ${ }^{34} 35$ 


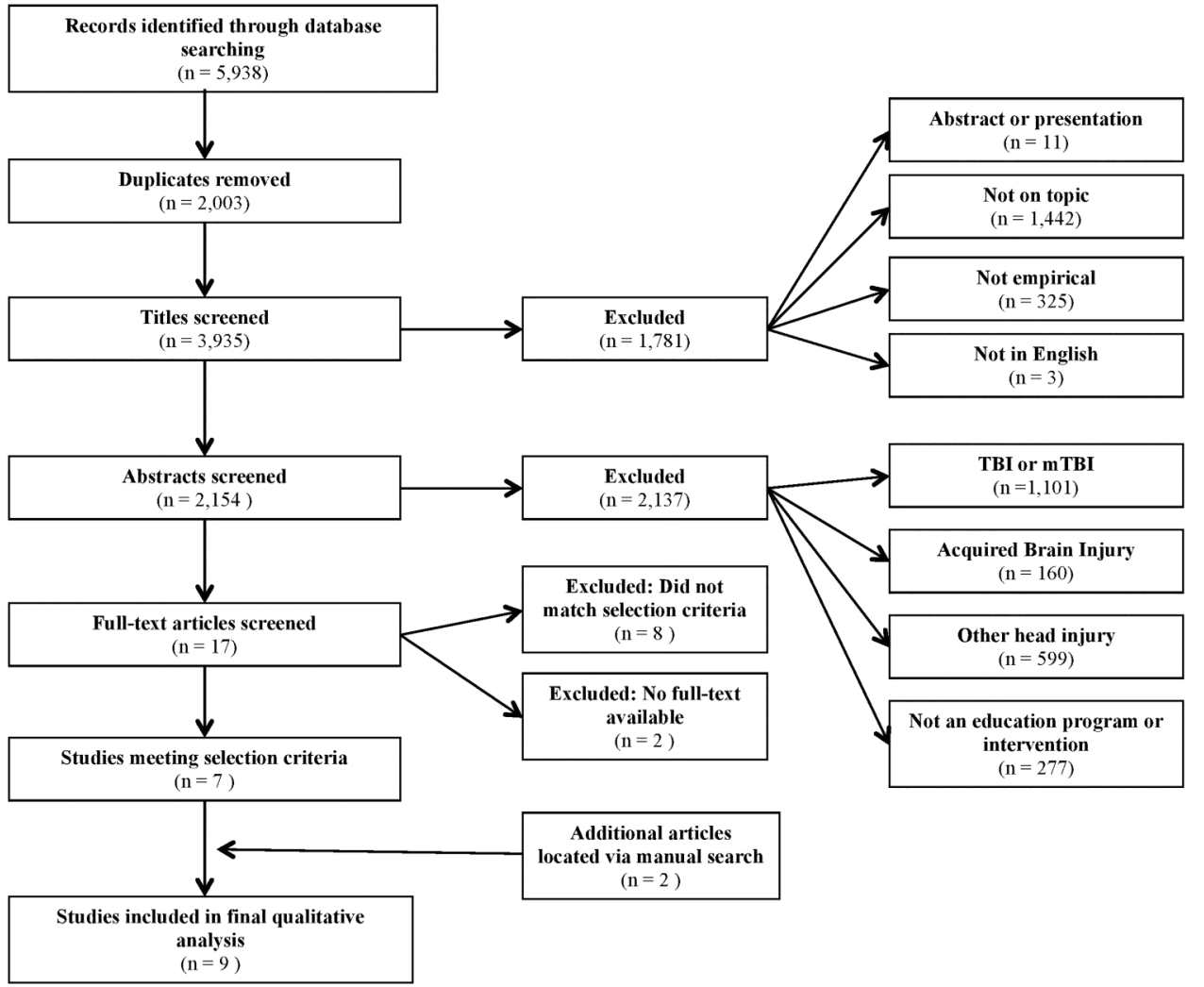

Figure 1 Illustration of research process. TBI, traumatic brain injury.

The instruments used to assess the concussion education programmes can be grouped into three categories: questionnaires and surveys, quizzes and other methods. Questionnaires and surveys were used by six studies to assess their concussion education programmes. ${ }^{25} 26 \quad 28-3033$ The Rosenbaum Concussion Knowledge and Attitudes Survey (RoCKAS) ${ }^{36}$ is one of the few standardised questionnaires used to assess the concussion knowledge and attitudes of students 13-20 years old. Interestingly, the RoCKAS was only used in one study. ${ }^{29}$ Three studies assessed their concussion education programmes using quizzes, ${ }^{27} 3132$ which involved a combination of free-response, true/false and multiple-choice questions. Finally, two studies used other methods to assess their concussion education programmes. For example, Cook et $a l^{25}$ examined the effect of their intervention by recording the number and type of aggressive penalties taken by youth ice hockey players during games. Using another method, Miyashita et $a l^{30}$ partially evaluated their concussion education programme by analysing collegiate athletes' responses to 'six qualitative questions' (ref. 30, p. 350) in order to create a score that represented the athletes' knowledge of concussions. In sum, the instruments used to assess concussion education programmes have predominantly used quantitative methods such as pre-presentation and post-presentation quizzes, questionnaires and surveys. Behaviour change ${ }^{25}$ and qualitative methods $^{30}$ are two rarely implemented methods that might be useful for evaluating concussion education programmes in the future.

The main outcomes of the studies revealed that some education programmes did not improve participants' knowledge, attitudes or behaviours related to concussions. ${ }^{26} 2729$ Despite this, the majority found that participants in the experimental groups demonstrated improved concussion knowledge immediately after exposure to the concussion education programme compared with their pre-presentation quiz scores or a control group. . $^{2} 262829 \quad 31-33$ One study from Glang et $a l^{33}$ reported short-term improvements in the experimental group's intention to take appropriate actions, such as removing an athlete from play who potentially suffered a concussion. Long-term improvements in concussion knowledge were reported up to 7 months after exposure to a concussion education programme. ${ }^{25} 2630$ For example, Cook et $a l^{25}$ found that youth ice hockey players in the experimental group took fewer aggressive penalties than the control group after being exposed to their education programme, which provides some evidence of behaviour change. Collectively, the majority reported short-term benefits after being exposed to their concussion education programme, ${ }^{25} 26282931-33$ while findings regarding the long-term benefits, such as improvements in participants' knowledge and behaviours, ${ }^{26}$ and attitudes, ${ }^{29}$ of concussions, were less clear. Details on participants' pre-intervention concussion knowledge were not provided. Only one study articulated that background information was not available. ${ }^{31}$ Presenting this information would provide insights on the outcomes of concussion education programmes, particularly with respect to those that did not find improvements in the experimental conditions.

\section{DISCUSSION}

The objective of this scoping review was twofold. The first purpose was to review the literature on concussion education programmes, and the second purpose was to inform concussion KT strategies. Results from this study determined that there are variations in contemporary concussion education programmes. This section will address the strengths, weaknesses and gaps in 


\begin{tabular}{|c|c|c|c|c|c|}
\hline Studies & Methodology & Participants & Programme & Instruments & Main outcomes \\
\hline Bagley et $a^{31}$ & $\begin{array}{l}\text { Non-randomised, pre-post study without a } \\
\text { control group. }\end{array}$ & $\begin{array}{l}599 \text { male }(n=309) \text { and female } \\
(n=290) \text { students were grouped } \\
\text { into three age categories: } 9-12 \\
(n=104), 13-15(n=310) \text { and } \\
16-18(n=148)(n=37 \text { age } \\
\text { unknown) }\end{array}$ & $\begin{array}{l}\text { Content: signs and symptoms, } \\
\text { short-term and long-term } \\
\text { consequences, and strategies for } \\
\text { responding to concussions } \\
\text { Delivery: } 40-60 \text { min audiovisual } \\
\text { presentation that contained video } \\
\text { segments, demonstrations, case studies } \\
\text { of professional and high school } \\
\text { athletes, personal testimonies and } \\
\text { question/answer period }\end{array}$ & $\begin{array}{l}\text { Identical pre- and post-programme quizzes } \\
\text { containing free-response, } T / F \text {, and } \\
\text { multiple-choice questions }\end{array}$ & $\begin{array}{l}\text { Improvements in absolute pre- and } \\
\text { post-quiz scores were observed across all } \\
\text { participants }(p<0.0001) \text {. More athletes } 13 \\
\text { and older passed the post-presentation quiz } \\
\text { ( } p<0.0001) \text {. Women showed greater } \\
\text { improvement than men }(p<0.0001)\end{array}$ \\
\hline Cook et $a l^{25}$ & $\begin{array}{l}\text { Randomised controlled, post-only study. } \\
\text { Two groups: experimental }(n=45) \text { and } \\
\text { control }(n=30)\end{array}$ & $\begin{array}{l}75 \text { male ice hockey players } \\
11-12 \text { years old }\end{array}$ & $\begin{array}{l}\text { Content: medical information, training } \\
\text { lessons and personal statements } \\
\text { Delivery: experimental group watched } \\
\text { 'Smart Hockey' video. Control group } \\
\text { received no intervention }\end{array}$ & $\begin{array}{l}\text { Two methods of assessment: two 'player } \\
\text { questions' assessed concussion knowledge } \\
\text { and game-by-game penalty analysis to } \\
\text { determine video's effect on behaviour }\end{array}$ & $\begin{array}{l}\text { Experimental group showed improvements } \\
\text { in knowledge and reduction in aggressive } \\
\text { penalties that were each maintained at } \\
3 \text { months }(p<0.05)\end{array}$ \\
\hline Cusimano et $a l^{26}$ & $\begin{array}{l}\text { Cluster randomised controlled, pre-post } \\
\text { study. Two groups: video }(n=61) \text { and } \\
\text { no-video }(n=74)\end{array}$ & $\begin{array}{l}135 \text { youth ice hockey players } \\
10 \text { years old }(n=89) \text { and } \\
14 \text { years old, }(n=46) \text {. Gender } \\
\text { was not reported }\end{array}$ & $\begin{array}{l}\text { Content: mechanisms of concussion, } \\
\text { in-game tactics to reduce high-risk } \\
\text { manoeuvres, and return to play } \\
\text { guidelines } \\
\text { Delivery: Video group watched the } \\
\text { ThinkFirst's 'Smart Hockey: More } \\
\text { Safety, More Fun' }\end{array}$ & $\begin{array}{l}\text { Two questionnaires were developed to assess } \\
\text { athletes' knowledge, and attitudes and } \\
\text { behaviours. They were administered at three } \\
\text { time points: immediately before and after } \\
\text { video, and } 2 \text { months later }\end{array}$ & $\begin{array}{l}\text { Increase in players' knowledge immediately } \\
\text { following the video ( } p<0.001 \text { ). } 10 \text {-year old } \\
\text { group showed post-video improvement but } \\
\text { decreased average scores at } 2 \text { months } \\
\text { (measure of significance were not provided). } \\
\text { The } 14 \text {-year-old group showed concussion } \\
\text { knowledge retention at } 2 \text { months (measure } \\
\text { of significance were not provided). No } \\
\text { differences in players' attitudes and } \\
\text { behaviours ( } p=0.507 \text { ) }\end{array}$ \\
\hline Echlin et $a l^{27}$ & $\begin{array}{l}\text { Randomised controlled, pre-post study. } \\
\text { Three groups: DVD }(n=16) \text {, interactive } \\
\text { computer module }(I C M)(n=20) \text {, and } \\
\text { control }(n=22)\end{array}$ & $\begin{array}{l}58 \text { male ice hockey players } \\
16-21 \text { years old }\end{array}$ & $\begin{array}{l}\text { Content: not explicitly stated } \\
\text { Delivery: experimental groups received } \\
\text { either the ThinkFirst DVD or ICM } \\
\text { intervention. Control group received no } \\
\text { intervention }\end{array}$ & $\begin{array}{l}26 \text { multiple-choice and } T / F \text { questions on } \\
\text { injury knowledge and treatment protocol. } \\
\text { Questions were readministered immediately } \\
\text { after intervention, and at } 2 \text { and } 4 \text { months }\end{array}$ & $\begin{array}{l}\text { No significant differences in knowledge } \\
\text { acquisition between groups, across the } \\
\text { times measured ( } p>0.05)\end{array}$ \\
\hline Glang et $a l^{33}$ & $\begin{array}{l}\text { Randomised controlled, post-only study. } \\
\text { Two groups: experimental }(n=40) \text { and } \\
\text { control }(n=35)\end{array}$ & $\begin{array}{l}75 \text { male }(n=52) \text { and female } \\
(n=23) \text { youth sport coaches. } \\
75 \% \text { self-identified as being } \\
\text { between } 30 \text { and } 49 \text { years old }\end{array}$ & $\begin{array}{l}\text { Content: prevention, recognition, and } \\
\text { management based on expert } \\
\text { guidelines }{ }^{34} 35 \\
\text { Delivery: experimental group completed } \\
\text { computer modules designed to deliver } \\
\text { concussion education. Control spent } \\
15-20 \text { min reviewing CDC materials }\end{array}$ & $\begin{array}{l}\text { Questionnaire assessed general knowledge, } \\
\text { symptoms, misconceptions, self-efficacy and } \\
\text { behaviour intention, and programme } \\
\text { satisfaction and acceptability }\end{array}$ & $\begin{array}{l}\text { Experimental group scored higher in general } \\
\text { knowledge }\left(\eta^{2}=0.37\right) \text {, symptoms }\left(\eta^{2}=0.46\right) \text {, } \\
\text { misconceptions }\left(\eta^{2}=0.12\right) \text {, self-efficacy } \\
\left(\eta^{2}=0.29\right) \text { and intention to take appropriate } \\
\text { actions }\left(\eta^{2}=0.17\right)\end{array}$ \\
\hline Goodman et $a^{28}$ & $\begin{array}{l}\text { Study } 1 \\
\text { Randomised controlled, post-only study. } \\
\text { Two groups: experimental }(n=65) \text { and } \\
\text { control ( } n=65) \\
\text { Study } 2 \\
\text { Randomised controlled, post-only study. } \\
\text { Two groups: experimental ( } n=16) \text { and } \\
\text { control ( } n=17)\end{array}$ & $\begin{array}{l}\text { Study } 1 \\
130 \text { ice hockey players aged } \\
11-12(n=44), 13-14(n=38) \\
\text { and } 15-17 \text { years old }(n=48) . \\
\text { Gender was not reported } \\
\text { Study } 2 \\
39 \text { ice hockey players } \\
13-14 \text { years old. Gender was } \\
\text { not reported }\end{array}$ & $\begin{array}{l}\text { Content: concussion symptoms } \\
\text { Delivery: experimental group played a } \\
\text { computer game where they stacked } \\
\text { icons that represented concussion } \\
\text { symptoms and non-symptoms. Control } \\
\text { group played the same game but icons } \\
\text { were not related to concussion }\end{array}$ & $\begin{array}{l}\text { A } 36 \text {-item questionnaire was developed and } \\
\text { administered after playing the game. Time to } \\
\text { complete the questionnaire was also } \\
\text { recorded. Computerised feedback } \\
\text { questionnaire provided to assess game } \\
\text { attributes }\end{array}$ & $\begin{array}{l}\text { Study } 1 \\
\text { Experimental group answered more } \\
\text { questions correctly ( } p<0.05 \text { ) and faster than } \\
\text { control ( } p<0.05) \text {. The game 'held the } \\
\text { interest' of } 90 \% \text { of } 11-12 \text { year olds, } 75 \% \text { of } \\
13-14 \text { year olds and } 60 \% \text { of } 15-17 \text { year } \\
\text { olds } \\
\text { Study } 2 \\
\text { Experimental group completed } \\
\text { questionnaire faster than control group } \\
\text { ( } p=0.015) \text {. Compared to study } 1 \text {, } \\
13-14 \text { year olds thought the game was } \\
\text { easier to play. No differences found in } \\
\text { symptom recognition }(p=0.055)\end{array}$ \\
\hline
\end{tabular}

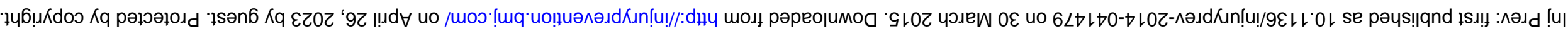


Table 1 Continued

\begin{tabular}{|c|c|c|c|c|c|}
\hline Studies & Methodology & Participants & Programme & Instruments & Main outcomes \\
\hline $\mathrm{Koh}^{32}$ & $\begin{array}{l}\text { Incidence cohort, pre-post study without a } \\
\text { control group }\end{array}$ & $\begin{array}{l}208 \text { male }(n=136) \text { and female } \\
(n=72) \text { university students from } \\
18 \text { to } 32 \text { years old registered in } \\
\text { a snowboarding class }\end{array}$ & $\begin{array}{l}\text { Content: concussion definition, } \\
\text { mechanism of injury, signs and } \\
\text { symptoms, post-concussion } \\
\text { management and return-to-play } \\
\text { Delivery: } 30 \text { min concussion safety } \\
\text { session using slides, videos and oral } \\
\text { presentation }\end{array}$ & $\begin{array}{l}\text { A } 20 \text {-item quiz was developed. Identical } \\
\text { quizzes were administered pre- and } \\
\text { post-educational intervention }\end{array}$ & $\begin{array}{l}\text { Significant increase in snowboard-related } \\
\text { concussion knowledge and awareness after } \\
\text { being exposed to the concussion safety } \\
\text { session }(p=0.00)\end{array}$ \\
\hline $\begin{array}{l}\text { Manasse-Cohick } \\
\text { and Shapley }{ }^{29}\end{array}$ & $\begin{array}{l}\text { Non-randomised pre-post study without a } \\
\text { control group }\end{array}$ & $\begin{array}{l}160 \text { high school football } \\
\text { players. Information on } \\
\text { athletes' age and gender was } \\
\text { not provided }\end{array}$ & $\begin{array}{l}\text { Content: general information about } \\
\text { concussions, causes and symptoms, } \\
\text { management, short-term and } \\
\text { long-term, and underreporting. Based } \\
\text { on Rosenbaum and Arnett's }{ }^{36} \text { survey. } \\
\text { Delivery: a } 5 \text { min modified video of } \\
\text { CDC's 'Heads Up: Concussion in High } \\
\text { School Sports-Information for } \\
\text { Coaches' followed by a } 20 \text { min } \\
\text { PowerPoint presentation, and a } \\
\text { question and answer period }\end{array}$ & $\begin{array}{l}\text { Participants answered identical pre- and } \\
\text { post-questionnaires. The Rosenbaum } \\
\text { Concussion Knowledge and Attitudes Survey } \\
\text { was used. Developed for students aged 13- } \\
20 \text { years, it contains three indices: concussion } \\
\text { knowledge index, concussion attitude index, } \\
\text { and validity scale }\end{array}$ & $\begin{array}{l}\text { Significant increase found in } \\
\text { post-intervention concussion knowledge } \\
\text { index }(p<0.000) \text { (Cohen's } d=1.05) \text { but not } \\
\text { with respect to the concussion attitude } \\
\text { index }(p=0.508)\end{array}$ \\
\hline Miyashita et $a l^{30}$ & $\begin{array}{l}\text { Cross-sectional, pre-post study without a } \\
\text { control group. Pre-intervention surveys } \\
\text { were completed during pre-participation } \\
\text { physical tests. Post-intervention surveys } \\
\text { were completed } 5 \text { months (soccer) and } \\
7 \text { months (basketball) months after the } \\
\text { intervention }\end{array}$ & $\begin{array}{l}50 \text { male }(n=27) \text { and female } \\
(n=23) \text { National Collegiate } \\
\text { Athletic Association division II } \\
\text { basketball and soccer players } \\
\text { average } 19.68 \text { years old }\end{array}$ & $\begin{array}{l}\text { Content: definition of concussion, signs } \\
\text { and symptoms, reporting process, } \\
\text { 'take-home guide', return-to-play } \\
\text { protocol, and long-term sequelae. } \\
\text { Based on 'athletic Training Education' } \\
\text { courses taught by lead investigator } \\
\text { Delivery: } 20 \text { min PowerPoint } \\
\text { presentation with } 10 \text { slides }\end{array}$ & $\begin{array}{l}\text { Pre- and post-intervention surveys contained } \\
\text { four quantitative questions to obtain athletes' } \\
\text { previous medical history and six qualitative } \\
\text { questions to ascertain athletes' concussion } \\
\text { knowledge }\end{array}$ & $\begin{array}{l}\text { Athletes scored significantly fewer incorrect } \\
\text { scores on the post-intervention surveys } \\
(p<0.0001)\end{array}$ \\
\hline
\end{tabular}


the existing literature and recommend strategies to improve future concussion education programmes.

Findings from this scoping review indicated that younger athletes scored worse on post-education programme assessments than older athletes. ${ }^{26}{ }^{31}$ Davis and Purcell ${ }^{37}$ found that athletes under the age of 14 experienced different symptoms than adults, which they attributed to differences in physical and cognitive maturity, neuroplasticity and protective abilities. Furthermore, youth athletes' concussion symptoms typically persist for longer periods of time. ${ }^{38} 39$ Experts have highlighted the importance of evaluating and managing youth and adult concussions differently. ${ }^{3}{ }^{37}$ As a result, we recommend that concussion education programmes are created, disseminated and assessed according to age group, ${ }^{9}$ which is consistent with the knowledge to action cycle.

There was discrepancy in the content of concussion education programmes. Often, authors provided few details about the content of their education programmes, including whether they were based on empirical research and/or expert guidelines. A number of guidelines and recommendations have been forwarded regarding best practices for concussion evaluation, management and return to play (activity) strategies. ${ }^{3} 4041$ Despite the availability of these guidelines, it remains unclear whether most of the concussion education programmes reviewed in this article were based on peer-review papers or expert guidelines and recommendations. We advise future research and intervention efforts to report the origins of the concussion information and content used in their programmes.

Evaluation of outcomes is standard practice in research and part of the knowledge to action cycle. ${ }^{9}$ In the reviewed studies, quantitative instruments such as quizzes, questionnaires and surveys were the most common evaluation methods. Additionally, two studies $^{25} 30$ evaluated the outcomes of their concussion education programmes using different methods that might prove beneficial for future investigations. For example, Cook et $a l^{25}$ evaluated hockey players' on-ice behaviours following their intervention. Evaluating the behavioural outcomes of concussion education programmes is important given that behaviour change such as reducing athletes' aggressive and reckless behaviours, as well as improving concussion-reporting behaviours, ${ }^{42-44}$ are important goals of concussion education. Given that health-related behaviour change has long been the focus of research and intervention, ${ }^{45}$ we recommend that research on concussion education programmes should focus more attention on assessing the behavioural outcomes of their interventions. Another strategy from Miyashita et $a l^{30}$ used a form of qualitative methods. However, the manner in which their data were collected and analysed suggests that qualitative methods were not used to their full potential. In brief, qualitative research is focused on providing detailed descriptions of human interactions, behaviours and experiences using methods that range from ethnography and document analysis to individual or group interviews. ${ }^{46}$ Interviewing is the most commonly used qualitative data collection strategy ${ }^{46}$ and has been recommended as an effective tool to evaluate KT interventions. ${ }^{47}$ One type of interviewing technique, focus groups, has commonly been used in health and management settings to help determine the effectiveness of interventions and programmes. ${ }^{48} 49$ Focus group interviews would allow participants to use their own words to provide a detailed description of the intervention, as well as offer insights on its strengths and weaknesses. ${ }^{9}$ Moreover, given that concussion education programmes are in their early stages of development, implementing qualitative focus group interviews would help advance the science and practice of concussion education programmes and concussion KT strategies.
Some of the weaknesses of the concussion education programmes reviewed in this study included limited use of interactive tools, delivery of education at one time point only and lack of long-term assessment. More research is needed to elucidate the factors that would improve participants' long-term knowledge, attitudes and behaviours after being exposed to a concussion education programme. One potential avenue to help overcome these limitations is to develop concussion education programmes that are delivered over multiple education sessions and the outcomes are assessed over longer periods of time, such as 6 months and 12 months post-delivery.

To further develop concussion education programmes, researchers should explore social media platforms such as Facebook, Twitter and YouTube ${ }^{50-52}$ or a combination of different strategies. For example, Sullivan et $a l^{51}$ hypothesised that Twitter, which allows users to 'tweet' messages up to 140 characters in length, could be an appropriate platform to disseminate concussion information and management strategies through short, coherent posts. However, social media platforms have yet to be incorporated into a concussion education programme. Another approach could be to integrate several different strategies such as videos, case studies, social media, handouts, oral presentations and discussions over a number of education sessions to accommodate different learning styles. ${ }^{7}$ More research is needed before we can conclusively recommend the best strategy for concussion education. Ultimately, researchers should consider the knowledge to action cycle when developing and implementing concussion education programmes, which will help to ensure that barriers and facilitators to knowledge use are assessed, the best strategy is selected and implemented, and the relevant outcomes are evaluated.

\section{CONCLUSIONS}

Despite being in their early stages of development, research suggests that interactive concussion education programmes can be an effective concussion KT strategy. Based on the findings from this scoping review, the following can be concluded:

- Concussion education programmes should use KT frameworks such as the knowledge to action cycle when developing, implementing and evaluating their programmes.

- Researchers must explicitly articulate the origins of concussion information that form the foundation of their education programmes.

- Given that qualitative methods have been suggested as a useful tool to evaluate KT interventions, ${ }^{47}$ focus group interviews may be an ideal methodology to evaluate concussion education programmes.

- Researchers must develop concussion education programmes aimed at improving participants' long-term knowledge, attitudes and behaviours.

- Future research and intervention should consider implementing concussion education programmes that integrate multiple strategies and social media platforms.

\section{What is already known on the subject?}

- Concussions are a contentious issue in modern sport.

- The effectiveness of using passive concussion education strategies such as handouts and websites has been questioned.

- Educating members of the sporting community about concussions is imperative to help prevent future injuries, as well as identify symptoms and manage recovery. 


\section{What this study adds?}

- Despite calls from experts, ${ }^{367}$ concussion education programmes have largely been developed without knowledge translation frameworks.

- The outcomes of concussion education programmes have primarily been evaluated using questionnaires, surveys and quizzes. Behaviour change $\mathrm{e}^{25}$ and qualitative methods ${ }^{30}$ are evaluation strategies that have rarely been implemented but are worthy of further investigation.

- A number of studies reported short-term improvements in participants' knowledge, attitudes and behaviours; however, the findings regarding the long-term benefits of concussion education programmes were less clear.

Acknowledgements We acknowledge the contributions of Jamie Rebner and Nikki Tummon for their assistance with this project.

Contributors JGC, the first guarantor, was involved in all aspects of the study including, planning, conducting and reporting the work in the article. GAB, the other guarantor, was involved in the planning of the project and oversaw all aspects of the article. WRF was involved in data collection, writing and editing sections of the article. SNS was involved in writing and editing sections of the article, in addition to giving feedback on his overall impression of the article.

\section{Competing interests None.}

Provenance and peer review Not commissioned; externally peer reviewed.

Data sharing statement The authors will share information regarding data collection upon request.

\section{REFERENCES}

1 Caron JG, Bloom GA, Johnston KM, et al. Effects of multiple concussions on retired National Hockey League players. J Sport Exerc Psychol 2013;35:168-79.

2 Carroll L, Rosner D. The concussion crisis: Anatomy of a silent epidemic. New York, NY: Simon \& Schuster, 2012

3 McCrory P, Meeuwisse WH, Aubry M, et al. Consensus statement on concussion in sport: The 4th International conference on concussion in sport held in Zurich, November 2012. Br J Sports Med 2013;47:250-8.

4 Adler RH, Herring SA. Changing the culture of concussion: Education meets legislation. Arch Phys Med Rehabil 2011;3:468-70.

5 Centers for Disease Control and Prevention. Concussion in Sport Policies. http:/l www.cdc.gov/concussion/policies.html (accessed 25 Feb 2015)

6 Provvidenza C, Engebretsen L, Tator C, et al. From consensus to action: knowledge transfer, education and influencing policy on sports concussion. Br I Sports Med 2013:47:332-8.

7 Provvidenza C, Johnston KM. Knowledge transfer principles as applied to sport concussion education. Br J Sports Med 2009;43:68-75.

8 Canadian Institutes of Health Research. Knowledge translation and commercialization. http://www.cihr-irsc.gc.ca/e/29418.html (accessed 9 Jun 2014).

9 Straus SE, Tetroe J, Graham ID. Knowledge translation in health care: Moving from evidence to practice. 2nd edn. West Sussex, UK: Wiley \& Sons, 2013.

10 Graham ID, Logan J, Harrison MB, et al. Lost in knowledge translation: Time for a map? J Contin Educ Health Prof 2006;26:13-24.

11 Sarmiento K, Hoffman R, Dmitrovski Z, et al. A 10-year review of the Centers for Disease Control and Prevention's Heads Up initiatives: Bringing concussion awareness to the forefront. I Safety Res 2014;50:143-7.

12 Chrisman SP, Schiff MA, Rivara FP. Physician concussion knowledge and the effect of mailing the CDC's "Heads Up" toolkit. Clin Pediatr (Phila) 2011;50: $1031-9$.

13 Covassin T, Elbin RJ, Sarmiento K. Educating coaches about concussions in sports: evaluation of the CDC's "Heads Up: Concussions in Youth Sport" initiative. J Sch Health 2012;82:233-7.

14 Sarmiento K, Mitchko J, Klein C, et al. Evaluating the Centers for Disease Control and Prevention's concussion initiative for high school coaches: "Heads Up for Concussion in High School Sport". J Sch Health 2010;80:112-18.

15 Ahmed OH, Sullivan SJ, Schneiders AG, et al. Concussion information online: Evaluation of information quality, content and readability of concussion-related websites. Br Sports Med 2012;46:675-83.
16 Grimshaw JM, Shirran L, Thomas R, et al. Changing provider behavior. An overview of systematic reviews of interventions. Med Care 2001;39:2-45.

17 Grant MJ, Booth A. A typology of reviews: An analysis of 14 review types and associated methodologies. Health Info Libr I 2009;26:91-108.

18 Arksey H, O'Malley L. Scoping studies: towards a methodological framework. Int $J$ Soc Res Methodol 2005;8:19-32.

19 Levac D, Colquhoun H, O'Brien K. Scoping studies: Advancing the methodology. Implement Sci 2010:5:1-9.

20 DeMatteo C, McCauley D, Stazyk K, et al. Post concussion return to play and return to school guidelines for children and youth: a scoping methodology. Disabil and Rehabil 2014 Published Online First Aug 21st 2014; (doi:10.3109/09638288. 2014.952452).

21 Affoo RH, Foley N, Rosenbek J, et al. Swallowing dysfunction and autonomic nervous system dysfunction in Alzheimer's disease: a scoping review of the evidence. J Am Geriatr Soc 2013;61:2203-13.

22 O'Brien K, Wilkins A, Zack E, et al. Scoping the field: Identifying key research priorities in HIV and rehabilitation. AIDS Behav 2010;14:448-58.

23 Moore L, Stelfox HT, Boutin A, et al. Trauma center performance indicators for nonfatal outcomes: a scoping review of the literature. I Trauma Acute Care Surg 2013;74:1331-43.

24 Paradis E, Leslie M, Gropper MA, et al. Interprofessional care in intensive care settings and the factors that impact it: results from a scoping review of ethnographic studies. J Crit Care 2013;28:1062-7.

25 Cook DJ, Cusimano MD, Tator D, et al. Evaluation of the ThinkFirst Canada, Smart Hockey, brain and spinal cord injury prevention video. Inj Prev 2003; 9:361-6.

26 Cusimano MD, Chipman M, Donnelly P, et al. Effectiveness of an educational video on concussion knowledge in minor league hockey players: a cluster randomized controlled trial. Br I Sports Med 2014;48:141-6.

27 Echlin PS, Johnson AM, Riverin S, et al. A prospective study of concussion education in 2 junior ice hockey teams: implications for sports concussion education. Neurosurg Focus 2010;29:1-4.

28 Goodman D, Bradley NL, Paras B, et al. Video gaming promotes concussion knowledge acquisition in youth hockey players. J Adolesc 2006;29: $351-60$.

29 Manasse-Cohick NJ, Shapley KL. Concussion education for high school football players: a pilot study. Commun Disord Q 2014;35:182-5.

30 Miyashita TL, Timpson WM, Frye MA, et al. The impact of an educational intervention on college athletes' knowledge of concussions. Clin J Sport Med 2013;23:349-53.

31 Bagley AF, Daneshvar DH, Schanker BD, et al. Effectiveness of the SLICE program for youth concussion information. Clin J Sport Med 2012;22:385-9.

32 Koh JO. Effect of snowboard-related concussion safety education for recognizing possible concussions. Sports Med Phys Fitness 2011;51:625-32.

33 Glang A, Koester MC, Beaver SV, et al. Online training in sports concussion for youth sports coaches. Int J Sports Sci Coach 2010;5:1-12.

34 McCrory P, Meeuwisse WH, Johnston KM, et al. Consensus statement on concussion in sport: The 3rd international conference on concussion in sport held in Zurich, November 2008. Br J Sports Med 2009;43:76-84.

35 Guskiewicz KM, Bruce SL, Cantu RC, et al. National Athletic Trainers' association position statement: management of sport-related concussion. J Athl Train 2004;39:280-97.

36 Rosenbaum AM, Arnett PA. The development of a survey to examine knowledge about and attitudes towards concussion in high school students. I Clin Exp Neuropsychol 2010;32:44-55.

37 Davis GA, Purcell LK. The evaluation and management of acute concussion differs in young children. Br J Sports Med 2014;48:98-101.

38 Field M, Collins MW, Lovell MR, et al. Does age play a role in recovery from sports-related concussion? A comparison of high school and collegiate athletes. J Pediatr 2003;142:546-53.

39 Grady MF. Concussion in the adolescent athlete. Curr Probl Pediatr Adolesc Health Care 2010;40:154-69.

40 Broglio SP, Cantu RC, Giola GA, et al. National athletic trainers' association position statement: Management of sport concussion. J Athl Training 2014;49:245-65.

41 Giza CC, Kutcher IS, Ashwal S, et al. Summary of evidence-based guideline update: Evaluation and management of concussions in sport: report of the guideline development of the American Academy of Neurology. Neurology 2013;80:2250-7.

42 Kroshus E, Baugh CM, Daneshvar DH, et al. Understanding concussion reporting using a model based on Theory of Planned Behavior. J Adolesc Health 2014;54:269-74

43 Register-Mihalik JK, Guskiewicz KM, Valovich McLeod TC, et al. Knowledge, attitude, and concussion-reporting behaviors among high school athletes: A preliminary study. I Athl Train 2013:48:645-53.

44 Register-Mihalik JK, Linnan LA, Marshall SW, et al. Using theory to understand high school aged athletes' intentions to report sport-related concussion: implications for concussion education initiatives. Brain Inj 2013;27:878-86. 
45 Riekert KA, Ockene JK, Pbert L. The handbook of health behavior change. 4th edn. New York, NY: Springer, 2014

46 Creswell JW. Qualitative inquiry and research design: choosing among five approaches. 3rd edn. Thousand Oaks, CA: Sage, 2013.

47 Straus SE, Tetroe J, Bhattacharyya O, et al. Monitoring knowledge use and evaluating outcomes, Chapter 3.5. In: Straus SE, Tetroe J, Graham ID, eds. Knowledge translation in health care: moving from evidence to practice. 2nd edn. West Sussex, UK: John Wiley \& Sons, 2013:227-36.

48 Krueger RA, Casey MA. Focus group: a practical guide for applied research. Thousand Oaks, CA: Sage Publications, 2000.
49 Rubin HJ, Rubin IS. Qualitative interviewing: the art of hearing data. Thousand Oaks, CA: Sage Publications, 2012.

50 Ahmed OH, Sullivan SJ, Schneiders AG, et al. iSupport: Do social networking sites have a role to play in concussion awareness? Disabil and Rehabil 2010;32:1877-83.

51 Sullivan SJ, Schneiders AG, Cheang C-W, et al. 'What's happening?' A content analysis of concussion-related activity on Twitter. Br J Sports Med 2012;46:258-63.

52 Williams D, Sullivan SJ, Schneiders AG, et al. Big hits on the small screen: An evaluation of concussion-related videos on YouTube. Br J Sports Med 2014;48:107-11.

\section{Pharmacy and hospital collaboration}

With a $\$ 1.3$ million grant, the Boston Medical Center will join with the US pharmacy, CVS, to study how to better dispense Narcan, used to treat opiate overdoses. All CVS pharmacies in Rhode Island and Massachusetts now keep Narcan in stock on a non-prescription basis. Editor's note: This is a splendid example of the sort of collaboration with pharmacies that is long overdue. (Noted by IBP)

\section{Opposition to Seattle gun tax plan}

Critics of Seattle's proposed new gun tax claim the study on which it is based is flawed. The study showed that "... someone admitted ... for a gun shot injury is 30 times more likely to be re-admitted for an additional gunshot injury than other non-injury patients admitted to the (same) hospital." Critics claim the subjects were all criminals but quote figures showing that only about one-half had a previous arrest. (Noted by IBP)

\section{Dangerous inflatable rides}

Injuries on inflatable objects like bouncy houses are increasing in the USA. The number of injuries has increased from about 5000 to 17000 in 10 years. Manufacturers recommend many safety measures but most are too detailed. It makes more sense to simply discourage the use of this type of 'entertainment' or to strengthen safety standards as onsumer product safety commission (CPSC) is now doing. (Noted by IBP)

\section{More shootings in New York}

For the second year, shootings in New York City have increased. There had been a major decline since the end of the 1990s. The new trend has taken on a political dimension, with the mayor's attempt to improve police-community relations being blamed. Police remain sceptical, because stop and frisk tactics are discouraged. This, in turn, reflects several well-publicised shootings by police, often of black victims. The mayor insists the shootings are due to 'a relatively small set of gangs and crews.' (Noted by IBP) 